\title{
RELASI GENDER, KETAHANAN KELUARGA DAN KUALITAS PERNIKAHAN PADA KELUARGA NELAYAN DAN BURUH TANI "BRONDOL" BAWANG MERAH
}

\author{
Herien Puspitawati*), Yasmin Azizah, Aditya Mulyana, Azmi Faatihatur Rahmah \\ Departemen IImu Keluarga dan Konsumen, Fakultas Ekologi Manusia, Institut Pertanian Bogor, \\ Bogor, 16680, Indonesia
}

*E-mail: herien_puspitawati@email.com

\begin{abstract}
Abstrak
Beberapa kajian sebelumnya menunjukkan bahwa kualitas pernikahan turut ditentukan oleh oleh relasi gender yang harmonis serta ketahanan keluarga yang baik. Penelitian ini bertujuan untuk menganalisis pengaruh relasi gender dan ketahanan keluarga terhadap kualitas perkawinan pada keluarga petani dan nelayan. Penelitian ini menggunakan desain cross sectional study dan dilakukan di Desa Pantai Sederhana, Kabupaten Bekasi dengan partisipan penelitian nelayan dan Desa Losari Lor, Kabupaten Brebes dengan partisipan penelitian buruh 'brondol' bawang. Partisipan penelitian dipilih secara purposive sampling dengan jumlah contoh sebanyak 130 keluarga. Hasil uji independent $t$-test menunjukkan bahwa keluarga nelayan memiliki relasi gender yang lebih baik dibandingkan dengan keluarga buruh tani. Kondisi ketahanan keluarga secara keseluruhan menunjukkan bahwa nelayan dan buruh tani memiliki perbedaan yang sangat signifikan. Secara keseluruhan rata-rata ketahanan keluarga buruh tani $(88,9)$ lebih tinggi dibandingkan keluarga nelayan $(83,7)$. Rata-rata indeks kualitas pernikahan keluarga nelayan $(84,7)$ lebih tinggi dibandingkan dengan keluarga buruh tani $(58,6)$. Hasil regresi menunjukkan bahwa faktor-faktor yang berpengaruh terhadap kualitas pernikahan adalah relasi gender, pendapatan per kapita, dan ketahanan keluarga. Oleh karenanya, keluarga nelayan dan keluarga buruh tani 'brondol' bawang merah diharapkan dapat meningkatkan relasi gender baik pada aktivitas publik, domestik, serta sosial kemasyarakatan serta meningkatkan ketahanan keluarga yang saat ini sudah baik sehingga kualitas pernikahan yang dihasilkan dapat meningkat.
\end{abstract}

Kata kunci: keluarga buruh tani, keluarga nelayan, ketahanan keluarga, kualitas pernikahan, relasi gender

\section{Gender Relations, Family Resilience and Quality of Marriage of Fisherman Family and Onion Farm Laborers}

\begin{abstract}
Previous research show that the quality of marriage is determined by harmonious gender relations and high family resilience. This study aims to analyze the influence of gender relations and family resilience on the quality of marriage in the families of farmers and fishermen. This study used a cross-sectional study design and was conducted in Pantai Sederhana Village, Bekasi Regency for participants of fishermen and Losari Lor Village, Brebes Regency for participants of peasant farmers of 'brondol' onions. The research participants was chosen by purposive sampling with a total sample of 130 families. The results of the independent t-test showed that fishermen's families had better gender relations compared to the families of peasant farmers. Overall, family resilience of fishermen and peasant farmers had a very significant difference. The average index of family resilience of peasant farmer families $(88,9)$ was higher than fishermen families $(83,7)$. The average quality of marriages of fisherman families $(84,7)$ was better than peasant farmers families $(58,6)$. Regression results indicate that the factors that influence the quality of marriage are gender relations, per capita income, and family resilience. Hence, the fishermen families and peasant families of red onion are expected to be able to improve gender relations whether in public, domestic and social activities as well as improve family resilience so the quality of the marriage will increase.
\end{abstract}

Keyword: family resilience, fisherman families, gender relations, peasant families, quality of marriage

\section{PENDAHULUAN}

Penelitian ilmu keluarga semakin meningkat dalam satu dekade terakhir di Indonesia dikarenakan adanya tantangan permasalahan keluarga yang semakin meningkat seperti munculnya berbagai tantangan keluarga
Indonesia dalam isu harmonisasi, komunikasi serta ekonomi (Saidiyah \& Julianto, 2016). Keluarga yang harmonis, komunikasi antaranggota keluarga yang baik, kondisi ekonomi yang mencukupi akan berperan oenting dalam mewujudkan kehidupan pernikahan yang berkualitas. Kualitas 
pernikahan yang dirasakan suami dan istri dapat dilihat dari kondisi kesehatan fisik yang lebih baik dan hubungan yang harmonis di dalam keluarga (Bulunda, Brown \& Yamashita, 2016). Berbagai hasil penelitian menunjukkan bahwa kualitas pernikahan dipengaruhi oleh gender, tingkat pendidikan, lama pernikahan, pilihan pasangan, pendapatan perkapita, pembagian peran, kepuasan pernikahan dan ketahanan dalam pernikahan (Allendorf \& Ghimire, 2013; Tyas, Herawati, \& Sunarti, 2017; Suitor, 1991; Xu \& Lai, 2004; Bradley \& Hojjat, 2017). Kualitas pernikahan dicirikan dengan adanya kepuasan pernikahan antara suami dan istri yang merupakan landasan dalam mewujudkan kelestarian keluarga dalam menjalankan siklus hidup berkeluarga. Kepuasan pernikahan merupakan sikap yang relatif stabil dan mencerminkan evaluasi keseluruhan individu dalam suatu hubungan pernikahan (Azeez, 2013).

Salah satu tujuan membentuk keluarga adalah untuk mewujudkan ketahanan keluarga dan kesejahteraan bagi anggota keluarganya. Berdasarkan UU Nomor 52 Tahun 2009, ketahanan dan kesejahteraan keluarga adalah "kondisi keluarga yang memiliki keuletan dan ketangguhan serta mengandung kemampuan fisik materil guna hidup mandiri dan mengembangkan diri dan keluarganya untuk hidup harmonis dalam meningkatkan kesejahteraan kebahagiaan lahir dan batin". Puspitawati (2017) mengungkapkan bahwa ketahanan keluarga menunjukkan suatu kekuatan baik dari sisi input, proses, maupun output bahkan dampak dari output yang dirasakan manfaatnya bagi keluarga serta kekuatan daya juang keluarga (coping strategy) dalam menyesuaikan diri dengan lingkungan. Menurut pandangan para ahli Burgess \& Locke (1960); Chapman (2000); Pearsall (1996); McCubbin et al. (1988); Otto (Mc Cubbin, 1988), secara garis besar ketahanan keluarga dicirikan oleh sikap melayani, keakraban antara suami istri, orang tua yang mengajar dan melatih anaknya, anakanak yang menaati dan menghormati orang tuanya, jiwa altruism antaranggota keluarga, pemeliharaan hubungan keluarga, atmosfer positif yang tercipta di dalam keluarga, martabat seluruh anggota keluarga yang selalu terlindungi, kemampuan individu atau keluarga untuk memanfaatkan potensinya menghadapi tantangan hidup, berjalannya fungsi-fungsi keluarga dalam menghadapi tantangan dan krisis, proses dinamis dalam keluarga untuk melakukan adaptasi positif terhadap bahaya dari luar dan dari dalam keluarga, keutuhan keluarga yang senantiasa terjaga, loyalitas, kerja sama dalam keluarga, fleksibilitas dalam melaksanakan peran keluarga, komunikasi yang efektif, pemenuhan kebutuhan spiritual keluarga, dan kuat dalam aspek kesehatan, ekonomi, pendidikan dan kehidupan bermasyarakat.

Badan Pusat Statistik (2017) menggambarkan bahwa kondisi keluarga di Indonesia masih rentan dan tergantung pada sektor pertanian dan kondisi alam. Menurut Survei Angkatan Kerja Nasional (SaKerNas) (2017), 40 juta dari 104 juta penduduk yang berumur 15 tahun ke atas bekerja sebagai petani. Sementara masyarakat pesisir yaitu keluarga nelayan tradisional termasuk pada masyarakat miskin dan tertinggal diantara kelompok masyarakat Iain (Saleha, Hartoyo, \& Hastuti, 2002). Kondisi ini mengindikasikan bahwa keluarga petani dan nelayan masih rentan dan tergantung terhadap kondisi alam di sekitarnya. Kondisi alam terus berubah menyebabkan keluarga harus mampu beradaptasi dan bertahan. Berdasarkan penelitian yang dilakukan oleh Walsh (2016), proses adaptasi yang dilakukan keluarga dapat memperkuat unit keluarga sehingga keluarga sebagai sistem fungsional dapat berjalan dengan baik.

Orientasi ketahanan keluarga berdasarkan pada keyakinan bahwa semua keluarga memiliki kekuatan dan potensi untuk berkembang, sehingga hal tersebut dapat menjadi faktor perlindungan dan pemulihan keluarga untuk mengamankan sumber daya serta membantu menumbuhkan ketahanan keluarga (Black \& Lobo, 2008). Oh dan Chang (2014) menyatakan bahwa terdapat lima konsekuensi yang terkait dengan ketahanan keluarga, yaitu menerima situasi, merubah perspektif kehidupan, peningkatan kualitas hubungan, memperkuat sikap yang pantang menyerah, dan peningkatan kesehatan keluarga. Hal tersebut mengindikasikan bahwa apabila keluarga petani dan nelayan dengan resiko kerentanan yang tinggi dapat mengoptimalkan ketahanan keluarganya maka keluarga tersebut dapat mengatasi permasalahan dan memenuhi kebutuhan hidup sehingga kepuasan pernikahan dapat tercapai.

Salah satu ciri keluarga menurut Burgess dan Locke (1960) adalah adanya kaitan interaksi dengan saling berkomunikasi dalam memerankan peran sosial antara suami dan istri. Peran sosial yang dimaksud adalah peran dalam rumah tangga, masyarakat, pembangunan, keluarga inti (extended family) maupun keluarga dalam arti luas (nuclear 
family) (Lestari, 2011). Kehidupan keluarga nelayan dan petani tidak terlepas dari pembagian peran antara suami dan istri. Bagi pasangan suami istri, peran dan relasi gender yang telah dilakukan sejak dahulu dapat bergeser atau menyatu, menciptakan suatu hubungan antara kepuasan pernikahan dan kesejahteraan (Carr et al., 2014). Saleha, Hartoyo, dan Hastuti (2002) menyatakan bahwa pada umumnya suami memiliki peran yang dominan pada kegiatan publik seperti mencari nafkah dan perempuan memiliki peran yang dominan pada kegiatan domestik seperti mengerjakan pekerjaan rumah tangga, mengasuh anak dan mengurus segala kebutuhan suami. Sebagai sebuah unit fungsional, keluarga akan terus menerus bertumbuh melalui relasi yang terbangun diantara anggota keluarganya termasuk relasi antara suami dan istri.

Relasi gender di dalam keluarga merujuk pada hubungan antara suami dan istri yang berkaitan dengan pembagian perannya (Puspitawati, 2012). Di dalam relasi gender terdapat aspek peran gender yang didasarkan pada harapan yang berbeda yang dimiliki oleh individu, kelompok, dan masyarakat berdasarkan jenis kelamin mereka dan juga berdasar kepada nilai-nilai dan keyakinan masyarakat tentang gender (Blackstone, 2003). Pengetahuan tentang peran dan relasi gender dalam rumah tangga berfokus pada bagaimana rumah tangga dapat melestarikan, menghasilkan dan mendiversifikasi sumber daya yang harus di andalkan pada saat krisis atau kesulitan yang ekstrem (Smyth et al., 2015). Smet (2009) menyatakan bahwa peran gender kemudian dapat digambarkan sebagai perilaku yang ditentukan dan diharapkan muncul dari individu oleh masyarakat berdasarkan jenis kelamin individu dan sesuai dengan posisinya di masyarakat. Peran gender pada gilirannya menentukan hubungan antara perempuan dan laki-laki di masyarakat (relasi gender). Relasi gender yang baik akan menghasilkan ketahanan yang baik pada keluarga dan kepuasan pernikahan yang baik. Relasi gender yang diterapkan dengan baik dapat membentuk keluarga menjadi lebih seimbang dan harmonis sehingga ketahanan keluarga secara berkelanjutan dapat dicapai.

\section{Azeez (2013) mengungkapkan bahwa} kepuasan pernikahan yang dirasakan tergantung atas kebutuhan individu, harapan, dan keinginan dari hubungan yang dijalaninya. Spanier (1979) menyatakan bahwa kualitas pernikahan mengacu pada fungsi dari pernikahan dan cara mengungkapkan perasaan suami istri dipengaruhi oleh fungsi tersebut. Kualitas pernikahan didefinisikan sebagai evaluasi secara subjektif dari hubungan suami dan istri dengan rentang evaluasi yang dapat mencerminkan karakteristik dari interaksi dalam pernikahan dan fungsi pernikahan. Kualitas pernikahan yang tinggi berhubungan dengan penyesuaian yang baik, komunikasi yang memadai, tingkat kebahagian perkawinan yang tinggi, dan tingkat kepuasan perkawinan yang tinggi. Hasil penelitian Razak et al. (2015) menemukan bahwa kualitas pernikahan dipengaruhi oleh berbagai aspek, salah satunya yaitu cara suami dan istri merespon stres yang dihadapi dan mencapai suatu kesepakatan. Seperti yang kita ketahui, stres tidak terlepas dari kehidupan pasangan suami istri dan bagaimana cara yang dilakukan suami istri untuk menghadapinya memainkan peran yang signifikan dalam meningkatkan kualitas pernikahan. Adanya kerja sama dan pembagian peran dan tugas yang optimal antara suami istri dalam melaksanakan kegiatan rumah tangga dapat mengoptimalkan ketahanan keluarga sehingga dapat menciptakan kualitas pernikahan yang kondusif.

Pendekatan teori yang digunakan dalam penelitian ini adalah struktural fungsional. Teori struktural fungsional menekankan kepada stabilitas dalam kehidupan sosial (Hudson, 1978). Salah satu aspek penting dari teori struktural fungsional adalah setiap keluarga yang sehat terdapat pembagian peran/fungsi keluarga yang jelas, dengan terpola dalam struktur hirarkis yang harmonis, dilandasi adanya komitmen terhadap pelaksanaan peran/fungsi tersebut (Puspitawati, 2012). Perspektif struktural fungsional menggambarkan keluarga sebagai unit sosial ekonomi, mempertahankan bahwa keluarga secara keseluruhan menyediakan seperangkat fungsi universal untuk masyarakat seperti pengaturan perilaku seksual, sosialisasi anak-anak, perawatan dan dukungan emosional, mempertahankan sistem ekonomi, dan menganugerahkan status sosial kepada anggotanya (Jardine \& Dallalfar, 2012). Salah satu konsep pendekatan sistem yang melandasi penelitian ini adalah konsep AGIL (Adaptation; Goal Attainment; Integration; and Latency), oleh Talcott Parsons yang menekankan pada adaptasi dengan lingkungan, adanya tujuan yang ingin dicapai, integrasi antar subsubsistem, dan pemeliharaan budaya atau norma/nilainilai/kebiasaan (Klein \& White, 1996). 
Pendekatan konsep AGIL tersebut selanjutnya dikaitkan dengan tiga variabel inti dalam penelitian ini yaitu relasi gender, ketahanan keluarga dan kualitas pernikahan. Berdasarkan paparan yang telah dirumuskan maka tujuan penelitian ini adalah: (1) membandingkan karakteristik keluarga, relasi gender, ketahanan keluarga, dan kualitas pernikahan pada keluarga nelayan dan petani buruh 'brondol' bawang merah, dan (2) menganalisis pengaruh relasi gender dan ketahanan keluarga terhadap kualitas perkawinan pada keluarga nelayan dan petani buruh 'brondol' bawang merah.

\section{METODE}

Penelitian ini menggunakan desain cross sectional study dan dilakukan di Desa Pantai Sederhana, Kecamatan Muara Gembong, Kabupaten Bekasi, Provinsi Jawa Barat untuk partisipan keluarga nelayan dan Desa Losari Lor, Kecamatan Losari, Kabupaten Brebes, Provinsi Jawa Tengah untuk partisipan keluarga buruh tani 'brondol' bawang merah. Pemilihan lokasi penelitian dilakukan secara purposive.

Populasi dari penelitian ini adalah keluarga yang suaminya bekerja sebagai buruh nelayan yang bertempat tinggal di Desa Pantai Sederhana, Kecamatan Muara Gembong, Kabupaten Bekasi, Provinsi Jawa Barat dan keluarga yang istrinya bekerja sebagai buruh tani 'brondol' bawang merah yang bertempat tinggal di Desa Losari Lor, Kecamatan Losari, Kabupaten Brebes, Provinsi Jawa Tengah. Responden dalam penelitian ini merupakan istri nelayan buruh dan perempuan buruh tani 'brondol' bawang merah. Teknik pemilihan contoh dilakukan secara purposive sampling dengan jumlah contoh adalah 130 keluarga yang terdiri atas 60 keluarga nelayan dan 70 keluarga buruh tani 'brondol' bawang merah.

Data primer yang dikumpulkan dalam penelitian ini adalah karakteristik responden dan keluarganya, relasi gender, ketahanan keluarga, dan kualitas pernikahan. Pengumpulan data dilakukan melalui wawancara dengan menggunakan kuesioner yang telah diuji reliabilitasnya. Karakteristik istri dan karakteristik keluarga terdiri atas usia suami dan usia istri, pendidikan suami dan pendidikan istri, besar keluarga, dan pendapatan keluarga. Usia suami dan isteri dikelompokkan menjadi tiga kelompok berdasarkan Hurlock (1980) yaitu kelompok usia dewasa awal (18-40 tahun), kelompok dewasa menengah (41-60 tahun), dan dewasa akhir (> 60 tahun). Pendidikan suami dan istri dikategorikan menjadi pendidikan dasar (1-9 tahun), pendidikan menengah (10-12 tahun), dan pendidikan tinggi ( $>12$ tahun). Kategori besar keluarga ditentukan oleh jumlah anggota keluarga menjadi tiga kategori berdasarkan BKKBN (2005) yaitu keluarga kecil ( $\leq 4$ orang), keluarga sedang (5-7 orang) dan keluarga besar (> 7 orang). Pendapatan keluarga dikategorikan menjadi dua kategori yaitu kurang dari atau sama dengan Rp416.058,00 dan lebih dari Rp416.058,00 untuk keluarga nelayan dan kurang dari atau sama dengan Rp338.815,00 dan lebih dari Rp338.815,00 untuk keluarga buruh tani "brondol" bawang merah. Pendapatan keluarga dibandingkan dengan garis kemiskinan Kabupaten Bekasi 2016 yaitu Rp416.058,00 dan garis kemiskinan Kabupaten Brebes 2017 yaitu Rp338.815,00 per bulan.

Relasi gender adalah hubungan antara lakilaki dan perempuan berkaitan dengan pembagian peran yang dijalankan masingmasing pada beragam tipe serta struktur keluarga (Puspitawati, 2012). Relasi gender dalam penelitian ini terdiri dari sembilan pertanyaan yang mencerminkan kerja sama suami dan istri dalam kegiatan memasak, menentukan menu masakan, melakukan pekerjaan rumah, merencanakan pendidikan anak, merawat anak yang sedang sakit, membuat perencanaan keuangan keluarga bersama-sama, berkomunikasi mencari pekerjaan sampingan, berpartisipasi dalam kegiatan rutin di $\mathrm{RT} / \mathrm{RW} /$ Kecamatan, dan berpartisipasi dalam kegiatan keagamaan. Kuesioner diukur menggunakan skala Likert (1-3), yaitu 1=tidak pernah; 2=kadang-kadang; $3=$ sering dengan nilai Cronbach's alpha sebesar 0,897. Instrumen ini merupakan modifikasi dari instrumen Krzaklewska (2014) dan Rahma, Puspitawati, dan Herawati (2015).

Kualitas pernikahan merupakan tolok ukur dalam melihat kelestarian integritas keluarga sehingga menjadi aspek penting dalam membentuk keluarga yang sejahtera (Bulunda, Brown, \& Yamashita, 2016). Kualitas pernikahan dalam penelitian ini terdiri dari dua pertanyaan. Kualitas pernikahan terdiri dari kebahagiaan pernikahan dan kepuasan pernikahan yang dirasakan istri. Kuesioner diukur menggunakan skala Likert (1-4), yaitu skor $1=$ sangat tidak puas; skor $2=$ tidak puas, skor $3=$ puas, dan skor 4=sangat puas dengan nilai Cronbach's alpha sebesar 0,886. Instrumen ini menggunakan modifikasi dari instrumen Lokshin dan Yemtsov (2001), 
Puspitawati (2012), dan Fower dan Olson (1993).

Ketahanan keluarga adalah kondisi dinamik suatu keluarga yang memiliki suatu keuletan dan ketahanan, serta mengandung ketahanan fisik material dan psikis mental spiritual guna hidup mandiri dan mengembangkan diri dan keluarganya untuk hidup harmonis dan meningkatkan kesejahteraan lahir batin sesuai dengan yang tercantum pada UU No. 10 Tahun 1992. Ketahanan keluarga dalam penelitian ini diukur dengan 30 pertanyaan yang terdiri atas enam dimensi yaitu legalitas dan struktur, ketahanan fisik, ketahanan ekonomi, ketahanan sosial psikologis, ketahanan sosial budaya, dan kemitraan gender. Kuesioner ini diukur menggunakan skala Likert (1-2), yaitu skor 1=tidak; dan skor $2=y a$ dengan nilai Cronbach's alpha 0,556. Instrumen ini menggunakan instrumen dari Puspitawati et al. (2015) dan Puspitawati, Herawati, dan Sarma (2018).

Data yang telah dikumpulkan diolah melalui proses editing, coding, scoring, entry data, cleaning data, dan dianalisis secara deskriptif dan statistik inferensia kemudian interpretasi data. Pengolahan data menggunakan Microsoft Excel dan untuk analisisnya menggunakan Statistical Package for Social Science (SPSS). Setelah entry dan cleaning data, dilakukan pengkategorian data terlebih dahulu. Pengkategorian dilakukan untuk mempermudah proses analisis. Pada saat melakukan pengolahan data pada variabel relasi gender, ketahanan keluarga dan kualitas pernikahan dibuat scoring data, kemudian hasil scoring tersebut dijumlahkan pada masing-masing variabel. Skor total kemudian ditransformasikan kedalam indeks.

Hasil penelitian pada penelitian ini dikategorikan dengan menggunakan cut off pengkategorian yaitu 00,0-50,0 dikategorikan rendah, 50,0 - 74,0 dikategorikan sedang dan $75,0-100,0$. Analisis deskriptif digunakan untuk menghitung nilai minimum, nilai maksimum, nilai rata-rata, dan standar deviasi. Statistika inferensia yang digunakan dalam penelitian ini adalah uji regresi linier berganda untuk mengetahui pengaruh karakteristik keluarga, relasi gender, dan ketahanan keluarga terhadap kualitas perkawinan pada buruh nelayan dan buruh tani 'brondol' bawang merah. Uji beda independent sample t-test digunakan untuk mengetahui perbedaan variabel-variabel antara buruh nelayan dan buruh tani 'brondol' bawang merah.

\section{HASIL}

\section{Karakteristik Istri dan Keluarga}

Hasil penelitian menunjukkan bahwa rata-rata usia istri berada pada kategori dewasa awal (38,3 tahun), sedangkan usia suami berada pada kategori usia dewasa madya (42,9 tahun). Persentase terbesar istri $(96,9 \%)$ dan suami $(98,3 \%)$ berada pada jenjang pendidikan dasar (1-9 tahun) dengan rata-rata lama pendidikan istri adalah 5,7 tahun dan suami 6,3 tahun. Data tersebut menunjukkan bahwa lama pendidikan istri yaitu tidak tamat SD sedangkan lama pendidikan suami setara dengan tamat SD. Berdasarkan besar keluarga, lebih dari setengah keluarga $(55,4 \%)$ termasuk ke dalam kategori keluarga kecil $(\leq 4$ orang). Jumlah minimal anggota dalam keluarga yaitu dua orang dan jumlah maksimal anggota keluarga adalah sebelas orang atau keluarga memiliki sembilan orang anak. Ratarata pendapatan per kapita keluarga nelayan sebesar Rp1.143.990,00 per bulan, yang artinya pendapatan per kapita per bulan berada di atas garis kemiskinan Kabupaten Bekasi tahun 2016, yaitu sebesar Rp416.000,00. Berbeda dengan keluarga nelayan, rata-rata pendapatan per kapita keluarga buruh tani sebesar Rp321.831,00 per bulan yang masih berada di bawah garis kemiskinan Kabupaten Brebes 2017 yaitu Rp338.816,00 per bulan. Hasil penelitian juga menunjukkan bahwa lebih dari empat perlima istri nelayan $(88,3 \%)$ tidak bekerja, sisanya ada yang bekerja sebagai pedagang dan kuli jaring. Adapun jenis pekerjaan suami yang paling banyak di keluarga buruh tani 'brondol' bawang merah adalah buruh tani $(21,4 \%)$, buruh bangunan $(15,7 \%)$, dan sisanya bekerja sebagai tukang becak, sopir, mekanik, konveksi, kondektur, peternak, kurir, mandor bawang, penjahit, satpam, petani, tukang kebun, dan wiraswasta.

\section{Relasi Gender}

Tabel 1 menunjukkan bahwa proporsi terbesar keluarga nelayan $(76,7 \%)$ mempunyai relasi gender pada kategori sedang, sedangkan proporsi terbesar $(81,4 \%)$ pada keluarga buruh tani 'brondol' bawang merah adalah relasi gender pada kategori rendah. Hal ini berarti keluarga nelayan memiliki relasi gender yang lebih baik dibandingkan dengan keluarga buruh tani 'brondol' bawang merah. Selain itu, hasil uji beda juga menunjukkan bahwa terdapat perbedaan yang sangat signifikan antara relasi gender keluarga nelayan dengan keluarga buruh tani 'brondol' bawang merah. 
Tabel 1 Sebaran keluarga berdasarkan kategori relasi gender antara keluarga nelayan dan keluarga buruh tani serta nilai minimum, maksimum, rata-rata, standar deviasi, dan keofisien uji beda

\begin{tabular}{|c|c|c|c|c|}
\hline \multirow[t]{2}{*}{ Kategori } & \multicolumn{2}{|c|}{$\begin{array}{c}\text { Nelayan } \\
(n=60)\end{array}$} & \multicolumn{2}{|c|}{$\begin{array}{l}\text { Buruh Tani } \\
(n=70)\end{array}$} \\
\hline & $\mathrm{n}$ & $\%$ & $\mathrm{n}$ & $\%$ \\
\hline $\begin{array}{l}\text { Rendah } \\
(00,0-50,0)\end{array}$ & 9 & 15,0 & 57 & 81,4 \\
\hline $\begin{array}{l}\text { Sedang } \\
(50,1-75,0)\end{array}$ & 46 & 76,7 & 13 & 18,6 \\
\hline $\begin{array}{l}\text { Tinggi } \\
(75,0-100,0)\end{array}$ & 5 & 18,3 & 0 & 0,0 \\
\hline Min-Maks & \multicolumn{2}{|c|}{$27,8-83,3$} & \multicolumn{2}{|c|}{$0-72,2$} \\
\hline $\begin{array}{l}\text { Rata- } \\
\text { rata } \pm \text { Stdev }\end{array}$ & \multicolumn{2}{|c|}{$56,8 \pm 11,068$} & \multicolumn{2}{|c|}{$25,7 \pm 20,574$} \\
\hline$p$-value & \multicolumn{4}{|c|}{$0,000^{\star * *}$} \\
\hline
\end{tabular}

Rata-rata relasi gender keluarga nelayan lebih tinggi $(56,8)$ daripada keluarga buruh tani 'brondol' bawang merah $(25,7)$.

Selain itu, penelitian ini juga menemukan adanya perbedaan yang signifikan di setiap pertanyaan relasi gender antara keluarga nelayan dan keluarga buruh tani 'brondol' bawang merah. Perbedaan tersebut disebabkan karena pada sebaran jawaban pada kerja sama suami istri dalam memasak dan menentukan menu masakan, melakukan pekerjaan rumah, merencanakan pendidikan anak, merawat anak yang sedang sakit, membuat rencana keuangan keluarga bersama-sama, komunikasi ketika akan mencari pekerjaan sampingan saat krisis keuangan, berpartisipasi dalam kegiatan rutin di lingkungan rumah, dan berpartisipasi dalam kegiatan keagamaan dengan rata-rata capaian indeks keluarga nelayan yang lebih tinggi dibandingkan rata-rata keluarga buruh tani 'brondol' bawang merah.

\section{Ketahanan Keluarga}

Hasil ketahanan keluarga total menunjukan bahwa pada keluarga nelayan mempunyai rata-rata indeks 83,7 dan keluarga buruh 'brondol' bawang dengan rata-rata indeks 88,9. Capaian tersebut menunjukkan bahwa keluarga buruh tani 'brondol' bawang merah lebih tahan dan lebih dapat menyesuaikan diri dengan keadaan lingkungannya daripada keluarga nelayan. Hal ini diperlihatkan dengan rata-rata perdimensi dari ketahanan keluarga. Pada empat dari enam dimensi, keluarga buruh tani 'brondol' bawang merah memiliki rata-rata yang lebih tinggi daripada keluarga nelayan (Tabel 2).
Tabel 2 Nilai rata-rata, standar deviasi, dan koefisien uji beda ketahanan keluarga dan dimensinya pada keluarga nelayan dan keluarga buruh tani

\begin{tabular}{|c|c|c|c|}
\hline \multirow[b]{2}{*}{ Dimensi } & Nelayan & Buruh Tani & \\
\hline & $\begin{array}{c}\text { Rata- } \\
\text { rata } \pm \text { Stdev }\end{array}$ & $\begin{array}{c}\text { Rata- } \\
\text { rata } \pm S t d e v\end{array}$ & $p$-value \\
\hline $\begin{array}{l}\text { Legalitas- } \\
\text { struktur }\end{array}$ & $77,8 \pm 26,516$ & $94,8 \pm 12,219$ & $0,000^{\star \star \star}$ \\
\hline $\begin{array}{l}\text { Ketahanan } \\
\text { Fisik }\end{array}$ & $88,8 \pm 18,078$ & $97,1 \pm 9,072$ & $0,002^{\star \star *}$ \\
\hline $\begin{array}{l}\text { Ketahanan } \\
\text { Ekonomi }\end{array}$ & $65,2 \pm 14,676$ & $64,6 \pm 15,402$ & 0,827 \\
\hline $\begin{array}{l}\text { Ketahanan } \\
\text { Sosial- } \\
\text { Psikologis }\end{array}$ & $99,0 \pm 4,396$ & $95,4 \pm 11,381$ & $0,017^{* *}$ \\
\hline $\begin{array}{l}\text { Ketahanan } \\
\text { Sosial- } \\
\text { Budaya }\end{array}$ & $76,7 \pm 21,524$ & $85,7 \pm 17,842$ & $0,010^{* * *}$ \\
\hline $\begin{array}{l}\text { Kemitraan } \\
\text { Gender }\end{array}$ & $95,0 \pm 11,424$ & $96,0 \pm 12,557$ & 0,638 \\
\hline $\begin{array}{l}\text { Ketahanan } \\
\text { keluarga } \\
\text { (total) }\end{array}$ & $83,7 \pm 81,759$ & $88,9 \pm 68,068$ & $0,000^{\star \star \star}$ \\
\hline
\end{tabular}

Legalitas-struktur. Hasil penelitian menunjukkan bahwa keluarga nelayan memiliki nilai rata-rata sebesar 77,8 dan keluarga buruh tani 'brondol' bawang merah memiliki rata-rata sebesar 94,8 (Tabel 2). Capaian kedua kelompok yaitu keluarga nelayan dan buruh tani 'brondol' bawang merah sama-sama berada pada kategori tinggi serta berbeda secara sangat signifikan. Perbedaan tersebut disebabkan karena pada sebaran jawaban dimensi legalitas struktur, buruh tani 'brondol' bawang memiliki skor yang jauh lebih tinggi dari keluarga nelayan dalam pertanyaan kepemilikan buku nikah dan akta kelahiran.

Tabel 3 Sebaran keluarga berdasarkan kategori kualitas pernikahan antara keluarga nelayan dan keluarga buruh tani serta nilai minimum, maksimum, rata-rata, standar deviasi, dan keofisien uji beda

\begin{tabular}{|c|c|c|c|c|}
\hline \multirow{2}{*}{ Kategori } & \multicolumn{2}{|c|}{ Nelayan } & \multicolumn{2}{|c|}{ Buruh Tani } \\
\hline & $\mathrm{n}$ & $\%$ & $\mathrm{n}$ & $\%$ \\
\hline $\begin{array}{l}\text { Rendah } \\
(00,0-50,0)\end{array}$ & 4 & 6,7 & 35 & 50,0 \\
\hline $\begin{array}{l}\text { Sedang } \\
(50,1-75,0)\end{array}$ & 18 & 30,0 & 27 & 38,6 \\
\hline $\begin{array}{l}\text { Tinggi } \\
(75,0-100,0)\end{array}$ & 38 & 63,3 & 8 & 11,4 \\
\hline Min-Maks & \multicolumn{2}{|c|}{$33,0-100,0$} & \multicolumn{2}{|c|}{$16,6-83,3$} \\
\hline $\begin{array}{l}\text { Rata- } \\
\text { rata } \pm \text { Stdev }\end{array}$ & \multicolumn{2}{|c|}{$84,72 \pm 18,229$} & \multicolumn{2}{|c|}{$58,6 \pm 14,114$} \\
\hline$p$-value & \multicolumn{4}{|c|}{$0,000^{* * *}$} \\
\hline
\end{tabular}


Ketahanan Fisik. Hasil penelitian menunjukan bahwa keluarga nelayan memiliki nilai rata-rata sebesar 88,8 dan keluarga buruh tani 'brondol' bawang merah memiliki nilai rata-rata 97,1 (Tabel 2). Meskipun capaian kedua kelompok eluarga nelayan dan buruh tani 'brondol' bawang merah berada pada kategori tinggi namun secara statistik berbeda secara sangat signifikan. Perbedaan tersebut disebabkan karena berdasarkan sebaran jawaban dimensi ketahanan fisik, keluarga buruh tani 'brondol' bawang merah terbebas dari keluarga yang memiliki penyakit akut/kronis atau cacat dan masalah gizi.

Ketahanan Ekonomi. Tabel 2 menunjukkan bahwa keluarga nelayan memiliki nilai rata-rata sebesar 65,2 dan keluarga buruh tani 'brondol' bawang merah dengan rata-rata 64,6 (Tabel 2). Hasil tersbeut menunjukkan bahwa keluarga nelayan dan buruh tani 'brondol' bawang merah sama-sama berada pada kategori sedang dan hasil uji beda tidak menunjukan perbedaan yang signifikan.

Ketahanan Sosial-Psikologis. Hasil menunjukkan bahwa keluarga nelayan memiliki nilai rata-rata sebesar 99,0 dan keluarga buruh tani 'brondol' bawang merah memiliki nilai rata-rata 95,4 (Tabel 2). Meskipun capaian indeks ketahanan sosialpsikologis kedua kelompok keluarga nelayan dan buruh tani 'brondol' bawang merah samasama berada pada kategori tinggi, uji beda statitisk menunjukkan adanya perbedaan signifikan. Perbedaan tersebut disebabkan karena pada sebaran jawaban dimensi ketahanan sosial-psikologis keluarga nelayan memiliki skor yang lebih tinggi dalam kepemilikan rumah, memiliki pekerjaan tetap dengan pendapatan berapa saja, memiliki tabungan dan tidak ada anak yang drop out dari sekolah.

Ketahanan Sosial-Budaya. Hasil penelitian memperlihatkan bahwa keluarga nelayan memiliki nilai rata-rata sebesar 76,7 dan keluarga buruh tani 'brondol' bawang merah memiliki nilai rata-rata 85,7 (Tabel 2). Capaian kedua kelompok keluarga nelayan dan buruh tani 'brondol' bawang merah sama-sama berada pada kategori tinggi. Hanya saja, secara statistic capaian keduanya berbeda secara sangat signifikan. Perbedaan tersebut terdapat pada ada tidaknya kekerasan antara suami dan istri, di keluaga buruh tani 'brondol' bawang merah ditemukan 8,9 persen pernah mengalami kekerasan antara suami dan istri.
Kemitraan Gender. Tabel 2 memperlihatkan bahwa keluarga nelayan memiliki nilai rata-rata sebesar 96,0 dan keluarga buruh tani 'brondol' bawang merah memiliki nilai rata-rata 95,0 (Tabel 2). Keluarga nelayan dan buruh tani 'brondol' bawang merah berada pada kategori tinggi dan hasil uji beda tidak menunjukan perbedaan yang signifikan.

\section{Kualitas Pernikahan}

Hasil penelitian seperti yang tersaji pada Tabel 3 menunjukkan bahwa sebesar 63,3 persen keluarga nelayan memiliki kualitas pernikahan yang tinggi sedangkan sebesar 50,0 persen keluarga buruh 'brondol' bawang masih berada di kategori rendah. Hal ini diperkuat dengan hasil uji beda yang menunjukkan bahwa terdapat perbedaan yang signifikan antara kualitas pernikahan keluarga nelayan dengan keluarga buruh 'brondol' bawang. Artinya kondisi kualitas pernikahan keluarga nelayan (rata-rata $=84,7)$ lebih baik dibandingkan dengan keluarga buruh 'brondol' bawang $(58,6)$.

Hasil penelitian juga menunjukkan adanya perbedaan yang signifikan pada tiap pertanyaan kualitas pernikahan. Perbedaan tersebut dapat dilihat lebih lanjut dari jawaban responden pada pertanyaan hubungan pernikahan dan hubungan individu dengan pasangannya. Hasil menunjukkan bahwa ratarata skor keluarga nelayan lebih tinggi dibandingkan dengan keluarga buruh tani 'brondol' bawang merah.

Tabel 4 Hasil uji regresi karakteristik istri, karakteristik keluarga, relasi gender, dan ketahanan keluarga terhadap kualitas pernikahan

\begin{tabular}{|c|c|c|c|}
\hline \multirow{2}{*}{ Variabel } & \multicolumn{3}{|c|}{ Kualitas Pernikahan } \\
\hline & (B) & $(\beta)$ & Sig \\
\hline Konstan & 19,622 & - & 0,255 \\
\hline $\begin{array}{l}\text { Lama pendidikan } \\
\text { istri }\end{array}$ & 0,571 & 0,071 & 0,380 \\
\hline $\begin{array}{l}\text { Lama pendidikan } \\
\text { suami }\end{array}$ & $-0,963$ & $-0,119$ & 0,149 \\
\hline Besar keluarga & 0,342 & 0,029 & 0,691 \\
\hline $\begin{array}{l}\text { Pendapatan perk } \\
\text { apita }\end{array}$ & $1,160 \mathrm{E}-5$ & 0,344 & $0,000^{* * *}$ \\
\hline Relasi gender & 0,348 & 0,421 & $0,000^{* * *}$ \\
\hline $\begin{array}{l}\text { Ketahanan } \\
\text { keluarga }\end{array}$ & 0,336 & 0,128 & $0,084^{*}$ \\
\hline $\mathrm{F}$ & & 14,688 & \\
\hline Adjusted $R$ Square & & 0,389 & \\
\hline Sig. & & 0,000 & \\
\hline
\end{tabular}




\section{Pengaruh Karakteristik Istri, Karakteristik Keluarga, Relasi Gender, dan Ketahanan Keluarga terhadap Kualitas Pernikahan}

Hasil uji analisis regresi menunjukan nilai Adjusted $R$ Square model adalah sebesar 0,389 . Hasil ini berarti bahwa model regresi dalam penelitian ini mampu menjelaskan pengaruh karakteristik istri, karakteristik keluarga, relasi gender, dan ketahanan keluarga terhadap kualitas pernikahan sebesar 38,9 persen. Sementara, sisanya sebanyak 61,1 persen dipengaruhi oleh variabel lain yang tidak terdapat dalam model. Hasil analisis juga menunjukkan bahwa pendapatan perkapita perbulan berpengaruh secara positif signifikan terhadap kualitas pernikahan $(\beta=1,160 \mathrm{E}-5, \quad p<0,01)$. Hal ini menunjukkan bahwa setiap peningkatan pendapatan perkapita perbulan menyebabkan meningkatnya kualitas pernikahan.

Selain itu, relasi gender berpengaruh positif signifikan terhadap kualitas pernikahan keluarga $(\beta=0,348, p<0,01)$. Artinya setiap kenaikan satu skor relasi gender akan menaikan kualitas pernikahan sebanyak 0,348 poin. Hal ini menunjukkan bahwa keluarga yang melakukan relasi gender dengan baik, akan berpengaruh terhadap meningkatnya kualitas pernikahan. Hasil lain dalam penelitian ini juga menemukan bahwa ketahanan keluarga berpengaruh positif signifikan terhadap kualitas pernikahan $(\beta=0,336, p<0,1)$. Artinya setiap kenaikan satu skor ketahanan keluarga akan menaikan kualitas pernikahan sebanyak 9,336 poin. Hal ini menunjukkan bahwa keluarga yang memiliki ketahanan keluarga yang tinggi berpengaruh terhadap meningkatnya kualitas pernikahan.

\section{PEMBAHASAN}

Relasi gender merupakan hubungan kerja sama, koneksi dan saling mendukung antara suami dan istri (March et al., 1999). Peran gender suami istri bersifat reciprocal (Eshelman, 1991). Pemahaman yang menyeluruh tentang peran gender sangat penting agar suami dan istri dapat melaksanakan perannya dalam keluarga dengan baik (Cetinkaya \& Gencdogan, 2014). Hasil penelitian menunjukkan bahwa relasi gender yang diterapkan oleh keluarga nelayan berada pada kategori sedang dan pada keluarga buruh tani 'brondol' bawang merah berada pada kategori rendah. Rata-rata relasi gender keluarga nelayan lebih baik dibandingkan dengan keluarga buruh tani 'brondol' bawang merah. Hasil ini menggambarkan bahwa keluarga nelayan sudah cukup baik dalam mengoptimalkan kerja sama suami dan istri dalam melakukan pekerjaan mengurus rumah, merawat dan mendidik anak, mengatur keuangan keluarga bersama-sama, berkomunikasi, dan turut andil dalam kegiatan sosial di masyarakat. Relasi gender antara keluarga nelayan dan keluarga buruh tani 'brondol' bawang merah, memiliki perbedaan yang sangat signifikan. Sa'diah (2016) menjelaskan bahwa kerja sama dan komunikasi yang terjalin dalam kehidupan keluarga dapat meningkatkan relasi gender antara suami istri. Relasi gender menentukan tanggung jawab suami istri atas pekerjaan yang dilakukan dalam kehidupan pernikahan (Avotri \& Walters, 2001). Pembagian pekerjaan tersebut tidak dilakukan berdasarkan konsep tubuh laki-laki dan tubuh perempuan, melainkan atas kerja sama yang harmonis dalam membangun keluarga (Nurlian \& Daulay, 2008). Penelitian yang dilakukan oleh Kiewisch (2015) mengungkapkan bahwa peran dan relasi gender memengaruhi kegiatan produktif yang dapat dilakukan seseorang, kemampuan mengakses sumber daya dibutuhkan untuk mengelola pendapatan dan nkegiatan yang berhubungan dengan mata pencaharian. Adanya peran gender tersebut bertujuan untuk mendistribusikan tugas dalam rangka menjaga efisiensi dan keseimbangan sistem keluarga dan masyarakat (Puspitawati, 2012). Siordia (2016) dalam penelitiannya menyatakan bahwa jejaring sosial yang dimiliki oleh keluarga mungkin terkait erat dalam pembentukan, dan pemeliharaan sikap suami dan istri terkait dengan peran gender yang mereka lakukan.

Ketahanan berfokus pada kemampuan individu atau rumah tangga untuk mengatasi guncangan dan tekanan dengan mengakses sumber daya dan mengatasi sumber stres (Kiewisch, 2015). Ketahanan memungkinkan keluarga untuk mengembangkan kehangatan, dukungan, dan kohesi (Black \& Lobo, 2008). Penelitian ini menemukan bahwa terdapat perbedaan yang sangat signifikan antara ketahanan keluarga secara keseluruhan yang dimiliki oleh keluarga nelayan dan keluarga buruh tani 'brondol' bawang merah. Penelitian ini menunjukan hasil yang berlawanan dengan relasi gender dan kualitas pernikahan, yaitu bahwa rata-rata ketahanan keluarga buruh tani 'brondol' bawang merah lebih tinggi dibandingkan keluarga nelayan. Hasil ini memperlihatkan bahwa keluarga buruh tani 'brondol' bawang merah sudah memiliki legalitas-struktur, ketahanan fisik, ketahanan sosial psikologis, dan ketahanan sosial budaya 
yang baik dibandingkan dengan keluarga nelayan. Secara detail dapat dikatakan bahwa dimensi legalitas-struktur, ketahanan fisik, dan ketahanan sosial-budaya pada keluarga buruh tani 'brondol' bawang merah lebih tinggi dibandingkan keluarga nelayan. Sebaliknya, dimensi ketahanan sosial-psikologis keluarga nelayan lebih tinggi dibandingkan dengan buruh tani 'brondol' bawang merah. Selanjutnya, dimensi ketahanan ekonomi dan kemitraan gender pada keluarga nelayan setara dengan keluarga buruh tani 'brondol' bawang merah. Sejalan dengan penelitian Sunarti (2001), ketika kebutuhan fisik keluarga terpenuhi dan terbebas dari masalah ekonomi maka keluarga tersebut dikatakan tahan secara fisik dan kemampuan mengelola emosi serta konsep diri yang baik menjadi kunci dalam menghadapi masalah-masalah keluarga nonfisik. Keluarga dapat memanfaatkan strategi koping dan ketahanan untuk memahami sumber daya dan kekuatan sendiri, sehingga memudahkan dalam menjalankan kehidupan keluarga sehari hari, membangun tujuan baru, dan mencari cara untuk mencapai tujuan tersebut (Mayordomo et al., 2016). Keluarga yang kuat dapat dijelaskan dengan adanya kemampuan yang dimiliki keluarga untuk merespon stres ataupun perubahan dalam dinamika kehidupan (Black \& Lobo, 2008). Keluarga yang memiliki ketahanan yang baik akan mencapai kesejahteraan hidup, sehat secara fisik serta mental, mencapai keberhasilan dalam pendidikan, pekerjaan dan membangun hubungan yang baik dengan lingkungan sekitar (Coyle, 2011).

Hasil penelitian menunjukan kualitas pernikahan nelayan berada pada kategori tinggi dan kualitas pernikahan buruh tani 'brondol' bawang merah berada pada kategori rendah. Hal tersebut terjadi karena keluarga nelayan merasa lebih puas dalam hubungan pernikahan dan hubungan dengan pasangan jika dibandingkan dengan keluarga buruh tani 'brondol' bawang merah. Penelitian ini juga menemukan bahwa terdapat perbedaan yang sangat signifikan antara kualitas pernikahan keluarga nelayan dan buruh tani 'brondol' bawang merah. Konsisten dengan relasi gender, kualitas pernikahan keluarga nelayan lebih baik dibandingkan dengan keluarga buruh tani 'brondol' bawang merah. Artinya, keluarga nelayan merasa lebih bahagia dan lebih puas dalam pernikahan daripada keluarga buruh tani 'brondol' bawang merah. Hal ini disebabkan karena untuk status pekerjaan nelayan yang harus melaut dan meninggalkan rumah selama berhari-hari tidak memungkinkan dilakukan oleh istri. Sementara itu, untuk status pekerjaan sebagai buruh tani 'brondol' bawang merah masih memungkinkan dilakukan oleh istri. Larasati (2012) menyatakan bahwa istri yang bekerja memiliki kemungkinan lebih besar untuk merasakan ketidakpuasan pernikahan. Ketidakpuasan pernikahan yang dirasakan istri terjadi apabila dukungan sosial yang diperoleh rendah dan dapat berdampak kepada hubungan pernikahan. Selain itu, kurangnya waktu bersama anak, stres, dan sulit mengerjakan pekerjaan rumah tangga merupakan permasalahan yang dimiliki oleh seorang istri yang bekerja (Nezhad et al., 2010).

Relasi gender memiliki pengaruh positif signifikan terhadap kualitas pernikahan. Hasil penelitian ini menunjukkan bahwa apabila keluarga dapat melalukan pembagian peran dan tugas dengan baik maka akan mengoptimalkan kualitas pernikahan yang dirasakan. Gender serta peran suami istri dalam perkawinan dapat mempengaruhi kepuasan serta kualitas pernikahan (Ogre, 2015; Centinkata \& Genchogan, 2014). Carr et al., (2014) mengatakan bahwa perubahan perkembangan dan peran selama perjalanan hidup suami istri berkontribusi pada kualitas perkawinan. Pendapatan perkapita berpengaruh positif signifikan terhadap kualitas pernikahan. $\mathrm{Hal}$ ini menunjukan apabila keluarga memiliki pendapatan perkapita lebih besar akan dapat mengoptimalkan kualitas pernikahan. Hasil penelitian ini sejalan dengan penelitian yang dilakukan oleh Tyas, Herawati, dan Sunarti (2017) yang menemukan bahwa pendapatan perkapita berpengaruh positif signifikan terhadap kualitas pernikahan.

Ketahanan keluarga memiliki pengaruh positif signifikan terhadap kualitas pernikahan. Hal ini menunjukan bahwa semakin baik ketahanan yang dimiliki keluarga akan mengoptimalkan kualitas pernikahan keluarga tersebut. Sejalan dengan penelitian yang dilakukan oleh Chapman (2000) yang menemukan bahwa kualitas perkawinan yang baik antara suami istri merupakan tanda ketahanan keluarga (Chapman, 2000). Kekuatan pernikahan juga dicerminkan dari kuatnya hubungan suami istri dengan adanya jiwa altruism, pemeliharaan hubungan, menciptakan atmosfer positif, melindungi martabat bersama, dan merayakan kehidupan bersama (Pearsall, 1996). Hasil penelitian ini juga sesuai dengan penelitian Puspitawati et al. (2018) yang menemukan bahwa ketahanan keluarga pada keluarga yang utuh dengan kondisi suami istri sangat erat, maka tiap dimensi maupun secara total 
mempunyai daya tahan dalam menyesuaikan hidup yang lebih baik dibandingkan dengan keluarga tunggal.

\section{SIMPULAN DAN SARAN}

Hasil penelitian ini menemukan bahwa ratarata pendapatan perkapita keluarga nelayan sebesar Rp1.143.990,00 per bulan, yang artinya pendapatan per kapita per bulan berada di atas garis kemiskinan Kabupaten Bekasi Tahun 2016. Berbeda dengan keluarga nelayan, rata-rata pendapatan per kapita keluarga buruh tani sebesar Rp321.831,00 per bulan yang masih berada di bawah garis kemiskinan Kabupaten Brebes Tahun 2017. Hasil uji beda independent $t$ - test menunjukkan bahwa keluarga nelayan memiliki relasi gender yang lebih baik dibandingkan dengan keluarga buruh tani 'brondol' bawang merah. Kondisi ketahanan keluarga nelayan dan buruh 'brondol' bawang merah memiliki perbedaan yang sangat signifikan $(p<0,01)$ pada dimensi legalitas-struktur, ketahanan fisik, ketahanan sosial-budaya, dan ketahanan sosialpsikologis. Secara keseluruhan rata-rata ketahanan keluarga buruh tani 'brondol' bawang merah $(88,9)$ lebih tinggi dibandingkan keluarga nelayan (83,7). Sementara itu, kualitas pernikahan keluarga nelayan (ratarata=84,7) lebih baik dibandingkan dengan keluarga buruh tani 'brondol' bawang merah $(58,6)$. Hasil regresi menunjukkan bahwa faktor-faktor yang berpengaruh terhadap kualitas pernikahan berdasarkan urutan kekuatan koefisien regresi adalah relasi gender, pendapatan perkapita, dan ketahanan keluarga.

Berdasarkan hasil penelitian, kualitas pernikahan dipengaruhi oleh relasi gender maka keluarga nelayan dan keluarga buruh tani 'brondol' bawang merah diharapkan dapat meningkatkan relasi gender baik pada aktivitas publik, domestik, serta sosial kemasyarakatan sehingga kualitas pernikahan yang dihasilkan dapat meningkat. Cara yang dapat dilakukan untuk meningkatkan relasi gender yaitu dengan mengefektifkan komunikasi dan keterbukaan terkait tugas yang dijalankan masing-masing. Kualitas pernikahan juga dipengaruhi oleh ketahanan keluarga maka keluarga nelayan dan keluarga buruh tani 'brondol' bawang merah diharapkan untuk selalu menjaga ketahanan keluarga yang saat ini sudah baik dan meningkatkannya agar kualitas pernikahan menjadi semakin baik. Saran yang diberikan untuk penelitian selanjutnya adalah dengan melakukan analisis perbandingan tipe keluarga yang mempunyai anak usia kecil dengan keluarga yang mempunyai anak remaja.

\section{DAFTAR PUSTAKA}

Avotri, J.Y., \& Walters, V. (2001). We women worry a lot about our husbands: ghanaian women talking about their health and their relationships with men. Journal of Gender Studies, 10(2), 197-211. doi: 10.1080/09589230120053319.

Azeez, A. E. P. (2013). Employed women and marital satisfaction: a study among female nurses International. Journal of Management and Social Sciences Research (IJMSSR), 2 (11). ISSN: 23194421.

Black, K. \& Lobo M. (2008). A conceptual review of family resilience factors. Journal of Family Nursing, 14(11): 33-55.

Blackstone, A. M. (2003) Gender roles and society. Human Ecology: An Encyclopedia of Children, Families, Communities, and Environments. 335-338. ISBN: I-57607852-3.

Bradley, J.M., \& Hojjat M. (2017) A model of resilience and marital satisfaction. $J$ Soc Psychol. 157(5): 588-601. doi: 10.1080/002245445.2016.1254592.

Bulunda, J.R., Brown, J.S., \& Yamashita, T. (2016). Marital quality, marital dissolution, and mortality risk during the later life course. Social Science \& Medicine. 165, 119-127. doi: $\underline{\text { 10.1016/i.socscimed.2016.07.025 }}$

Burgess, E. W., \& Locke, J.L. (1960). The Family (2nd ed). New York: American Book Company.

Carr, D., Freeman, V. A., Cornman, J. C., \& Schwarz, N. (2014). Happy marriage, happy life? Marital quality and subjektive well-being in later life. Journal of Marriage and Family. 930-948. Doi: 10.111/jomf.12133

Chapman, G. (2000). Five Signs of a Functional Family (Lima Tanda Keluarga yang Mantap). Batam: Interaksara.

Coyle, J. P. (2011). Resilient families help make resilient children. Journal of Family Strengths, 11(1): 1-16.

Eshelman, J. R. (1991). Family. Boston: Allyn and Bacon Inc.

Fatima, M., \& Ajmal, M. A. (2012). Happy marriage: a qualitative study. Pakistan 
Journal of Social and Clinical Psychology, 9(2): 37-42.

Jardine, S. D., \& Dallalfar, A. (2012). Sex and gender roles: examining gender dynamics in the context of African American Families. Journal of Pedagogy, Pluralism and Practice. 4(4), 18-26.

Kiewisch, E. (2015). Looking within the household: a study on gender, food security, and resilience in cocoa-growing communities. Gender \& Development, 23 (3), 497-513. doi: 10.1080/13552074.2015.1095550.

Klein, D. M., \& White, J. M. (1996). Family Theories. An Introduction. Thousand Oaks. London. New Delhi: SAGE Publications. International Education and Professional Publisher.

Krzaklewska, E. (2014). Measurement of gender equality analyzing dimensions, embracing areas, considering contexts. Working paper no. 1.2 "Gender Equality and Quality of Life-State of Art Report".

Larasati, A. (2012). Kepuasan perkawinan pada istri ditinjau dari keterlibatan suami dalam menghadapi tuntutan ekonomi dan pembagian peran dalam rumah tangga. Jurnal Psikologi Pendidikan dan Perkembangan, 1(03), 1-6.

Lestari, P. (2011). Peranan dan status perempuan dalam sistem sosiap. DEMENSIA, 5(1): 45-60.

Lokshin, M., \& Yemtsov, R. (2001). Household strategies for coping with poverty and social exclusion in post-crisis Russia 2556. World Bank Publications.

Mayordomo, T., Viguer, P., Sales, A., Satorres, E., \& Meléndez, J.C. (2016). Resilience and coping as predictors of well-being in adults. The Journal of Psychology, 0(0), $1-13$. doi: 10.1080/00223980.2016.1203276.

McCubbin, H. I., Joy, C. B., Cauble, A. E., Comeau, J. K., Patterson, J.M., \& Needle, R. H. (1988). Family Stress and Coping: A Decade Review. Journal of Marriage and the Family, 42, 855-871.

Nezhad, M. Z., Goodarzi, A.M., Hasannejad, L., \& Roushani, K. (2010). Occupational stress and family difficulties of working women. Current Research in Psychology, 1(2): 75-81. ISSN 1949-0178.

Nurlian., \& Daulay, H. (2008). Kesetaraan gender dalam pembagian kerja pada keluarga petani ladang (studi kasus analisa isu gender pada keluarga petani ladang di Desa Cot Rambong, Kecamatan Kuala, Kabupaten Nagan Raya, NAD). Jurnal Harmoni Sosial. 2(2): 76-82.

Oh, S., \& Chang, S. J. (2014). Concept analysis: family resilience. Journal of Nursing, 4: 980-990.

Pearsall, P. (1996). Rahasia Kekuatan Keluarga: Membangkitkan Kekuatan Hidup Keluarga untuk Memperkokoh Membangkitkan Kembali, dan Menyembuhkan. Pustaka Delapratasa: Jakarta.

Puspitawati, H. (2012). Gender dan Keluarga: Kondep dan Realita di Indonesia. Bogor (ID): IPB Press.

Puspitawati, H., Herawati, T., Hastuti, D., Sumarti, T \& Sarma, M. (2015). Pengembangan Model Ooperasional Pendataan Ketahanan Keluarga untuk Kegiatan Pembangunan di Tingkat Kabupaten. Laporan Penelitian. Kerja sama antara Kementerian Pemberdayaan Perempuan dan Perlindungan Anak- Republik Indonesia dengan Pusat Kajian Gender dan AnakLPPM-IPB.

Puspitawati, H., Herawati, T., Rahma, A. (2016). Telaah pengintegrasian perspektif gender dalam keluarga untuk kesetaraan dan keadilan gender dan ketahanan keluarga di provinsi Jawa Timur dan Sumatera Utara. Kerja sama Kementerian Pemberdayaan Perempuan dan Perlindungan Anak Republik Indonesia dan Lembaga Penelitian dan Pegambidan Kepada Masyarakat Institut Pertanian Bogor.

Puspitawati, H., Herawati, T., \& Sarma, M. (2018). Reliabilitas dan Validitas Indikator Ketahanan Keluarga di Indonesia. Jurnal Kependudukan Indonesia. 13(1): 1-14. E-ISSN: 25028537

Rahma, A., Puspitawati, H., \& Herawati, T. (2015). Pengaruh peran gender dan pemeliharaan lingkungan mikro terhadap kesejahteraan subjektif keluarga petani dataran tinggi. Jurnal IImu Keluarga dan Konsumen. 8(2), 69-79. doi: 10.24156/jikk.2015.8.2.69

Razak, S. N. F. A,, Hoesi, S. M., Zakaria, E., \& Ismail, R. (2015). The role of dyadic coping of marital quality-the conceptual paper. Procedia Social and Behavioral 
Science. 211: 911-916. Doi: 10.1016/j.sbspro.2015.11.120.

Sa'diah, Z. (2016). Relasi gender dalam keluarga pasangan pernikahan difabel di Kudus Jawa Tengah. PALASTREN. 9(1): 43-68.

Saidiyah, S \& Julianto V. Problem pernikahan dan strategi penyelesaiannya: studi kasus pada pasangan suami istri dengan usia perkawinan dibawah sepuluh tahun. Jurnal Psikologi Undip, 15(2): 124-133.

Saleha, Q., Hartoyo., \& Hastuti D. (2008). Managemen sumber daya keluarga: suatu analisis gender dalam kehidupan keluarga nelayan di pesisir Bontang Kuala, Kalimantan Timur. Jurnal IImu Keluarga dan Konsumen. 1(2), 118-130. doi: 10.24156/jikk.2008.1.2.118.

Spanier, G. B. (1979). The measurement of marriage quality. Journal of Sex and Marital Therapy, 5(3): 288-300. Doi: http://dx.doi.org/10.1080/0092623790840 3734

Siordia, C. (2016) on the relationship between gender roles attitudes, religious ideology and familism in a sample of adults in the United States. Journal of International Women's Studies, 17(4): 229-244.

Suitor, J. J. (1991). Marital quality and satisfaction with the division of household labor across the family life cycle. Journal of Marriage and the Family, 53: 221-230.

Sunarti, E. (2001). Studi ketahanan keluarga dan ukurannya: telaah kasus pengaruhnya terhadap kualitas kehamilan (Disertasi). Institut Pertanian Bogor, Bogor, Indonesia

Sunarti, E., Johan, I. R., \& Christine H. (2010). Hubungan Fungsi Agil dengan Kesejahteraan Keluarga yang rawan terkena bencana alam. Jurnal IImu Keluarga dan Konsumen, 3(1): 11-12. Doi: 10.24156/jikk.2010.3.1.11

Smet, S. (2009). A widow of opportunity improving gender relations in post-conflict societies: the Sierra Leone experience. Journal of Gender Studies, 18(2): 147163.

Smyth, I., \& Sweetman, C. (2015). Introduction: Gender and Resilience. Gender \& Development. 23(3), 405-414. doi: 10.1080/13552074.2015.1113769.

Tyas, F.P. S., Herawati, T., \& Sunarti, E. (2017). Tugas perkembangan keluarga dan kepuasan pernikahan pada pasangan menikah muda. Jurnal IImu Keluarga dan Konsumen. 10(2), 83-94. doi: 10.24156/jikk.2017.10.2.83.

Walsh, F. (2016). Family resilience: a developmental systems framework. European Journal of Developmental Psychology. 1-12. Doi: http: 10.1080/17405629.2016.1154035

Xu, X., Lai, S. C. (2004). Gender ideologies, marital roles, and marital quality in Taiwan. Journal of Family Issues. 25(3): 318-355.

doi: 